\title{
HUBUNGAN KONSUMSI TABLET FE DENGAN KEJADIAN ANEMIA PADA IBU HAMIL DI DESA BAREGBEG WILAYAH KERJA PUSKESMAS BAREGBEG KABUPATEN CIAMIS TAHUN 2018
}

\author{
Ana Samiatul Milah ${ }^{1}$ \\ ${ }^{1}$ Program Studi Keperawatan Fakultas Ilmu Kesehatan Universitas Galuh Ciamis
}

(Diterima 17-4 Oktober 2018; disetujui 15 -12-2018; dipublish 31-1-2019)

\begin{abstract}
ABSTRAK
Anemia merupakan suatu keadaan dimana kadar hemoglobin Pada ibu hamil dibawah normal, karena itu ibu hamil memerlukan tambahan zat besi salah satunya bersumber dari tablet Fe. Menurut data yang ada di Desa Baregbeg tahun 2018 Pada Bulan Februari - April 2018 memiliki capaian pemberian tablet Fe paling rendah yaitu sebesar $51.4 \%$, sehingga ibu hamil yang mengalami anemia mencapai masih tinggi yaitu mencapai $51.3 \%$. Penelitian ini bertujuan untuk mengetahui hubungan konsumsi tablet fe dengan kejadian anemia pada ibu hamil. Penelitian ini bermanfaat bagi bidan dalam upaya meningkatkan pelayanan di bidang kesehatan guna meningkatkan kepatuhan ibu hamil dalam mengkonsumsi tablet $\mathrm{Fe}$. Jenis penelitian ini termasuk kuantatif dengan menggunakan metode analitik dengan pendekatan cross sectional. Populasi dalam penelitian ini adalah seluruh ibu hamil sebanyak 31 orang yang diperoleh dengan teknik total sampling. Data diperoleh menggunakan lembar kuesioner dan format isian kemudian Dianalisis secara univariat dan uji chi square. Dari hasil penelitian menunjukkan bahwa Konsumsi tablet fe pada ibu hamil,.

Sebagian besar termasuk kategori teratur (54.8\%), Ibu hamil sebagian besar tidak mengalami anemia (61.3\%).hasil uji statistic diperoleh terdapat hubungan konsumsi tablet fe dengan kejadian anemia pada ibu hamil dengan $p$ value 0,002. Kesimpulan dari penelitian ini terdapat hubungan antara konsumsi teblet Fe dengan angka kejadian anemia pada ibu hamil.Oleh karena itu Sebaiknya ibu hamil dapat mengkonsumsi tablet Fe secara teratur sesuai dengan anjuran dari petugas kesehatan sehingga dapat mencegah kejadian anemia.
\end{abstract}

Kata Kunci $\quad$ : Konsumsi Tablet Fe, Anemia. Kepustakaan $\quad$ : $23(2007-2017)$

\section{PENDAHULUAN}

Penyebab utama kematian ibu yaitu perdarahan (25\%), infeksi (15\%), hipertensi dalam kehamilan (12\%), partus macet (8\%) dan aborsi (13\%) (Saifuddin, 2010). Perdarahan sebagai penyebab tertinggi merupakan dampak dari komplikasi/ penyakit saat kehamilan dan persalinan seperti anemia. Perdarahan yang hebat tersebut akan berdampak pada pada kondisi syok atau menurunnya kesadaran akibat banyaknya darah yang keluar. Hal ini menyebabkan gangguan sirkulasi darah ke seluruh tubuh dan dapat menyebabkan hipovolemia berat sehingga dapat menyebabkan kematian (Taufan,2012).

Anemia selama kehamilan dapat berdampak pada komplikasi peresalinan seperti terjdinya perdaahan perdarahan postpartum. Setiap ibu hamil dengan anemia memiliki risiko untuk terjadi 
perdarahan postpartum. Hal ini terjadi karena ketidakmampuan uterus untuk berkontraksi yang adekuat. Pada anemia jumlah sel darah merah yang aktif berkurang, sehingga mempengaruhi jumlah kadar haemoglobin dalam darah (Manuaba, 2008).

Anemia yang sering dijumpai dalam kehamilan adalah anemia karena kekurangan zat besi (fe) sehingga lebih dikenal dengan istilah anemia gizi besi (AGB) (Sulityoningsih, 2013). Menurut Manuaba (2008) ibu hamil yang mengalami anemia berdampak buruk terhadap kehamilan, persalinan dan nifas. Dampak pada kehamilan diantaranya adalah abortus, kelahiran prematur, infeksi, hyperemesis gravidarum, perdarahan antepartum dan ketuban pecah dini. Pada persalinan akan berdampak pada gangguan kontraksi berkurang, persalinan berlangsung lama dan dampak pada pasca terjadinya sub involusi uterus, ASI berkurang serta infeksi puerperium.

Menurut WHO kejadian Anemia hamil berkisar antara $60 \%$ dengan menetapkan $\mathrm{Hb} \quad 11$ gr \% $\quad$ sebagai dasarnya.Menurut Kemenkes RI (2016) prevalensi anemia di Indonesia tergolong tinggi, hasil survei beberapa fakultas kedokteran di Indonesia pada tahun 2017 menemukan 50-63\% ibu hamil menderita anemia. Di Indonesia sebagian besar anemia pada ibu hamil disebabkan karena kekurangan zat besi $(\mathrm{Fe})$ hingga disebut anemia kekurangan zat besi atau anemia gizi besi pada kehamilan.
Secara nasional cakupan ibu hamil mendapat tablet $\mathrm{Fe}$ (fe lengkap) tahun 2016 sebesar $85,17 \%$, tidak berbeda jauh dibanding tahun 2014 yang sebesar $85,1 \%$. Karyadi (2017) mengatakan prevalensi anemia pada ibu hamil di Indonesia tahun 2014 sekitar 40-50\% atau 5 dari 10 ibu hamil mengalami gangguan kesehatan anemia. Ibu hamil tidak menyadari bahwa kurangnya konsentrasi haemoglobin saat hamil bisa berdampak serius bagi janin.

Sedangkan untuk Jawa Barat cakupan ibu hamil yang mendapat tablet Fe mencapai $95,51 \%$ dari 979.472 kehamilan, sementara itu prevalensi anemia sebesar 41\%. Namun hal ini berbeda dengan cakupan di Kabupaten Ciamis dimana cakupan ibu hamil yang mendapat zat besi pada tahun 2015 mencapai $89.33 \%$ dari 36.168 orang, kemudian pada tahun 2016 meningkat menjadi $96.68 \%$ dari 32.507 ibu hamil, sedangkan kejadian anemia juga relatif tinggi yaitu mencapai $33,8 \%$ dari target 13\% (Dinas Kesehatan Kabupaten Ciamis, 2017).

Amanda (2013) menambahkan upaya pemerintah dalam mengatasi anemia defisiensi besi ibu hamil yaitu terfokus pada pemberian tablet tambahan darah $(\mathrm{Fe})$ pada ibu hamil. Departemen Kesehatan masih terus melaksanakan progam penanggulangan anemia defisiensi besi pada ibu hamil dengan membagikan tablet besi atau tablet tambah darah kepada ibu hamil sebanyak satu tablet 
setiap satu hari berturut-turut selama 90

hari selama masa kehamilan.

Salah satu upaya untuk pencegahan dan pengobatan anemia adalah dengan konsumsi zat besi yang banyak terkandung dalam Tablet Fe. Zat besi (Fe) merupakan mikro elemen essensial bagi tubuh yang diperlukan dalam sintesa hemoglobin. Konsumsi tablet $\mathrm{Fe}$ sangat berkaitan dengan kadar hemoglobin pada ibu hamil. Anemia defesiensi zat besi yang banyak dialami ibu hamil disebabkan oleh kepatuhan mengonsumsi tablet $\mathrm{Fe}$ yang tidak baik ataupun cara mengonsumsi yang salah sehingga menyebabkan kurangnya penyerapan zat besi pada tubuh ibu.

Prevalensi anemia pada ibu hamil berdasarkan laporan Dinas Kesehatan Kota Tasikmalaya tahun 2015 berkisar 3.137 orang $(6,3 \%)$ dari 49.853 orang. Data yang penulis peroleh dari Puskesmas Baregbeg diperoleh kasus anemia pada kehamilan tahun 2015 sebanyak 207 orang $(38,1 \%)$ dari 543 ibu hamil, sedangkan pada tahun 2017 mengalami peningkatan dimana jumlah ibu hamil anemia sebanyak 244 orang (51.9\%) dari 470ibu hamil, hal ini lebih tinggi bila dibandingkan dengan Puskesmas Indihiang dimana ibu hamil yang mengalami anemia sebanyak 138 kasus (29.3\%) dari 471 ibu hamil, sedangkan di Puskesmas Padakembang mencapai 142 kasus (27.3\%) dari $521 \mathrm{ibu}$ hamil (Dinkes Ciamis, 2017).

Beberapa kondisi ibu yang memperberat anemia diantaranya adalah jarak kehamilan yang terlalu dekat, hal ini disebabkan karena ibu hamil belum pulih kembali dari persalinan sebelumnya. Seorang ibu yang sering melahirkan mempunyai risiko mengalami anemia pada kehamilan berikutnya apabila tidak memperhatikan kebutuhan nutrisi, zat besi dalam tubuh yang rendah sebagai akibat ketidakpatuhan dalam mengkonsumsi tablet $\mathrm{Fe}$, penyakit kronik, perdarahan dan gangguan asupan nutrisi (Mardalena, 2017).

Definisi Kehamilan, Ibu hamil adalah seorang wanita yang tidak menstruasi biasanya ditandai dengan keluarnya kolostrum, buah dada membesar, mual-muntah serta bila dilakukan test urine hasilnya positif. Kehamilan mulai dari konsepsi sampai lahirnya janin, lamanya hamil normal adalah 280 hari (40 minggu) atau 9 bulan 7 hari dihitung dari hari pertama haid terakhir (Mansjoer, 2009).

Masa kehamilan dimulai dari konsepsi sampai lahir janin. Lama kehamilan normal yaitu 280 hari atau 40 minggu atau 10 bulan (lunar months). Kehamilan dibagi atas 3 triwulan yaitu triwulan pertama dimulai dari konsepsi sampai 3 bulan (0-12 minggu), triwulan kedua dari bulan ke-4 sampai 6 bulan (1228 minggu), triwulan ketiga dari bulan ke7 sampai 9 bulan (28-40 minggu) (Saifudin, 2010).

Perubahan Fisiologis kehamilan

a. Perubahan Fisik

1) Volume darah

Volume darah total dan volume plasma darah naik pesat 
sejak akhir trimester I. Volume darah akan bertambah kira-kira 25 persen dengan puncaknya pada kehamilan 32 minggu, diikuti curah jantung (cardiac output) yang meningkat sebanyak kirakira 35 persen. Kenaikan plasma darah dapat mencapai 40 persen mendekati kehamilan cukup bulan.

b. Perubahan Psikis

Kehamilan adalah saat sensitif bagi seorang wanita, selama kehamilan kebanyakan wanita mengalami perubahan psikologis dan emosional tentang berbagai masalah dari satu trimester ke trimester selanjutnya Beberapa ibu hamil tidak dapat menghindari derajat ansietas atau stres pada saat-saat tertentu (Harna, 2008)

c. Perubahan Hematologi

Selama hamil, terjadi perubahan pada sistem tubuh wanita, diantaranya terjadi perubahan pada sistem reproduksi, sistem pencernaan, sistem perkemihan, sistem musculoskeletal, sistem endokrin, sistem kardiovaskuler, sistem hematologi, dan perubahan pada tanda-tanda vital. Pada masa postpartum perubahan-perubahan tersebut akan kembali menjadi seperti saat sebelum hamil. Kelainan hematologi yang sering terjadi adalah adanya penurunan jumlah sel darah merah yaitu anemia. Terjadi akibat produksi darah merah dari sumsum tulang berkurangyang diakibatkan oleh kekurangan faktor untuk eritropoesis, seperti asam folat, vitamin B12, dan besi.(Brunner,2012)

Anemia adalah suatu keadaan dimana kadar hemoglobin dalam darah dibawah normal. Hal ini disebabkan karena kurangnya gizi untuk pembentukan darah seperti kekurangan zat besi, asam folat ataupun vitamin B12 (Sulistyoningsih, 2013).

Anemia secara praktis didefinisikan sebagai kadar hematokrit, konsentrasi $\mathrm{Hb}$ atau hitung eritrosit dibawa batas normal. WHO menetapkan anemia dalam kehamilan adalah kondisi ibu dengan kadar $\mathrm{Hb}$ di bawah 11 gr\% pada trimester I dan III atau kadar HB $<10,5$ gr\% pada trimester II (Nurmiaty, 2010).

Anemia adalah suatu keadaan adanya penurunan kadar hemoglobin hematokrit dan jumlah eritrosit di bawah nilai normal. Pada penderita anemia, lebih sering disebut kurang darah, kadar sel darah merah (hemoglobin atau HB) di bawah nilai normal.

Anemia lebih sering dijumpai dalam kehamilan, hal itu disebabkan karena dalam kehamilan keperluan akan zat-zat makanan bertambah dan terjadi pula perubahan-perubahan dalam darah dan sumsum tulang. Darah bertambah banyak dalam kehamilan, yang lazim disebut 
hidremia atau hipervolemia. Akan tetapi, bertambahnya sel-sel darah kurang dibandingkan dengan bertambahnya plasma, sehingga terjadi pengenceran darah.

Pengenceran darah dianggap sebagai penyesuian diri secara fisiologi dalam kehamilan dan bermanfaat bagi wanita. Pertama-tama pengenceran itu meringankan beban jantung yang harus bekerja lebih berat dalam masa hamil, karena sebagai akibat hidremia cardiac output meningkat. Kerja jantung lebih ringan apabila viskositas darah rendah. Resistensi perifer berkurang pula, sehingga tekanan darah tidak naik. Kedua, pada perdarahan waktu persalinan, banyaknya unsur besi yang hilang lebih sedikit dibandingkan dengan apabila darah itu tetap kental.

Bertambahnya darah dalam
kehamilan sudah mulai sejak
kehamilan umur 10 minggu dan
mencapai puncaknya dalam kehamilan
antara 32 dan 36 minggu.

Adapu Kebutuhan zat besi pada ibu hamil wanita memerlukan zat besi lebih tinggi dari laki-laki karena terjadi menstruasi dengan perdarahan sebanyak 50-80 cc setiap bulan dan kehilangan zat besi sebesar 30-40 mg. Di samping itu kehamilan memerlukan tambahan zat besi untuk meningkatkan jumlah sel darah merah dan membentuk sel darah merah janin juga plasenta sebagai gambaran berapa banyak kebutuhan zat besi pada kehamilan adalah sebagai berikut:

a. Meningkatkan sel darah ibu 500 $\mathrm{mg} \mathrm{Fe}$

b. Terdapat dalam plasenta $300 \mathrm{mg}$ $\mathrm{Fe}$

c. Untuk darah janin $100 \quad \mathrm{mg}$ Fe.

Jumlah kebutuhan zat besi pada ibu hamil adalah $900 \mathrm{mg}$ Fe selama kehamilan.

Tanda dan Gejala, Dalam kehamilan adalah keluhan seperti lemas, pucat, mudah pingsan, sering pusing, mata berkunang-kunang, lidah luka, nafsu makan turun (anoreksia), konsentrasi hilang, nafas pendek (pada anemia parah) dan keluhan mual muntah lebih hebat pada hamil muda, perubahan jaringan epitel kuku.

Diagnosa Anemia pada Kehamilan, Untuk menegakkan anemia pada kehamilan dapat dilakukan dengan anamnesa. Pada anamnesa akan didapat keluhan cepat lelah, sering pusing, mata berkunang kunang dan keluhan mual muntah lebih hebat pada hamil muda. Pemeriksaan dan pengawasan HB dapat dilakukan dengan menggunakan alat sahli dilakukan minimal dua kali selama kehamilan, yaitu pada trimester I dan pada trimester III. Pembagian anemia menurut kadar HB dalam darah sebagai berikut (Manuaba, 2008):

Hb 11 gr\% : tidak anemia

$\mathrm{Hb} 9-10,5 \mathrm{gr} \% \quad$ : anemia ringan

$\mathrm{Hb} 7-8$ gr\% : anemia sedang 
$\mathrm{Hb}<7 \mathrm{gr} \% \quad$ : anemia berat

Dengan pertimbangan bahwa sebagian ibu hamil mengalami anemia, maka dilakukan pemberian preparat FE sebanyak 90 tablet pada ibu hamil.

Jenis-Jenis Anemia

Anemia Defisiensi Besi, Anemia dalam kehamilan yang sering dijumpai ialah anemia akibat kekurangan besi. Kekurangan ini dapat disebabkan karena kurang masuknya unsur besi dengan makanan, karena gangguan resorbsi, atau karena terlampau banyaknya besi keluar dari badan, misalnya perdarahan.

1) Diagnosa

Sifat yang khas dari anemia defisiensi besi adalah:

a) Kadar besi serum tinggi

b) Daya ikat besi serum tinggi

c) Protoporifin eritrosit tinggi

2) Pencegahan

a) Sulfas Ferrosus atau glukonas 1 tablet sehari

b) Makan lebih banyak protein dan sayur-sayuran yang mengandung banyak mineral serta vitamin

c) Ferrum oksidum sakkaratum, sodium diferrat dan dekstran besi secara IV

d) Transfusi darah.

Anemia Megaloblastik, Anemia megaloblastik disebabkan karena defisiensi asam folik, jarang sekali karena defisiensi vitamin B12.
1) Diagnosa

Diagnosa anemia megaloblastik dibuat apabila ditemukan megaloblastik atau pramegaloblas dalam darah atau sumsum tulang. Pemeriksaan asam formimino glutamik dalam air kencing dapat membantu dan percobaan pengeluaran asam folik.

2) Pencegahan

Apabila pengobatan anemia dengan besi saja tidak berhasil, maka besi harus ditambahkan dengan asam folik.

3) Terapi

Tablet asam folik diberikan dalam dosis 15-30 mg sehari, apabila disebabkan oleh defisiensi vitamin B12, maka diberi vitamin B12 dengan dosis 100-1000 mg sehari baik peros maupun parental.

a. Anemia Hemolitik

Anemia hemolitik

disebabkan karena penghancuran sel darah merah berlangsung lebih cepat dari pembuatannya. Pengobatan anemia hemolitik dalam kehamilan tergantung pada jenis dan beratnya.

Pengobatan anemia hemolitik dalan kehamilan tergantung pada jenis dan beratnya. Obat-obat penambah darah tidak memberi hasil. Transfusi darah, yang 


$$
\begin{aligned}
& \text { kadang-kadang di ulang } \\
& \text { beberapa kali, diperlukan } \\
& \text { pada anemia berat untuk } \\
& \text { meringankan penderitaan ibu } \\
& \text { dan mengurangi bahaya } \\
& \text { hipoksia pada janin. }
\end{aligned}
$$

b. Anemia Hipoplastik

Anemia ini disebabkan
karena sumsum tulang
kurang mampu membuat sel kurang mampu membuat sel sel darah baru. Sumsum tulang bersifat normoblastik dengan hipoplasia erithopoesis yang nyata. Ciri lain adalah bahwa pengobatan dengan segala macam obat penambah darah tidak memberi hasil.

Etiologi anemia ini belum jelas, kecuali yang disebabkan oleh sepsis, sinar rontgen, racun atau obatobatan, satu satunya cara untuk memperbaiki keadaan ini adalah transfusi darah.

Pengaruh Anemia pada Kehamilan dan Janin

Menurut Manuaba pengaruh anemia adalah sebagai berikut :

a. Bahaya selama kehamilan

1) Dapat terjadi abortus

2) Persalinan prematur

3) Hambatan tumbuh kembang janin dan rahim

4) Mudah terjadi infeksi

5) Ancaman decompensasi cordis $(\mathrm{Hb}<6 \mathrm{gr} \%)$
6) Mola hidatidosa

7) Hyperemesis gravidarum

8) Perdarahan antepartum

9) Ketuban pecah dini.

b. Bahaya saat persalinan

1) Gangguan his dan kekuatan mengedan

2) Kala I dapat berlangsung lama

3) Kala II dapat berlangsung lama sehingga melelahkan

4) Kala III dapat terjadi retensio plasenta dan perdarahan postpartum karena atonia uteri

5) Kala IV dapat terjadi perdarahan postpartum sekunder dan atonia uteri.

c. Bahaya saat nifas

1) Terjadi sub involusi uteri

2) Memudahkannya infeksi purperium

3) Pengeluaran asi berkurang

4) Terjadi dekompensasi kordis mendadak setelah persalinan.

Proses metabolisme zat besi digunakan untuk biosintesa hemoglobin, dimana zat besi digunakan secara terus-menerus. sebagian besar zat besi yang bebas dalam tubuh akan dimanfaatkan kembali (Reutilization), dan hanya sebagian kecil sekali yang di ekresikan melalui air kemih, feses dan keringat. 
Suplementasi zat besi, Peparat zat besi oral adalah : Ferrous sulfonat, glukonat dan fumarat. Prinsip pemberian terapi zat besi oral, Tidak boleh dihentikan setelah hemoglobin mencapai nilai normal, tetapi harus dilanjutkan selama 2-3 bulan lagi untuk memperbaiki cadangan besi.

Maurer menganjurkan pemberian zat besi selama 2-3 bulan setelah hemoglobin menjadi normal. Beutler mengemukakan bahwa yang penting dalam pehgobatan dengan zat besi adalah agar pemberiannya diteruskan dahulu sampai morfologi darah tepi menjadi normal dan cadangan besi dalam tubuh terpenuhi. Sebelum dilakukan pengobatan harus dikalkulasikan terlebih dahulu jumlah zat besi yang dibutuhkan.

$$
\text { Misalnya Hemoglobin }
$$
sebelumnya adalah $6 \mathrm{gr} / \mathrm{dl}$, maka kekurangan Hemoglobin adalah $12-6=6$ gr $/ \mathrm{dl}$, sehingga kebutuhan zat besi adalah: 6 x 200 mg. Kebutuhan besi untuk mengisi cadangan adalah $500 \mathrm{mg}$, maka dosis Fe secara keseluruhan adalah $1200+500=1700 \mathrm{mg}$. Fero sulfat : 3 tablet / hari, a $300 \mathrm{mg}$ mengandung $60 \mathrm{mg} \quad \mathrm{Fe}$ Fero glukonat : 5 tablet / hari, a $300 \mathrm{mg}$ mengandung $37 \mathrm{mg}$ Fe. Fero fumarat : 3 tablet / hari, a $200 \mathrm{mg}$ mengandung $67 \mathrm{mg}$ Fe. Efek samping: Konstipasi, berak hitam, mual dan muntah.

Respon hasil yang dicapai adalah $\mathrm{Hb}$ meningkat 0,3-1 gr per minggu, biasanya dalam 4-6 minggu perawatan hematokrit meningkat sampai nilai yang diharapkan, peningkatan biasanya dimulai pada minggu ke 2 . Peningkatan retikulosit 5-10 hari setelah pemberian terapi besi bisa memberikan bukti awal untuk peningkatan produksi sel darah merah.

Pemberian zat besi parenteral, Metode sederhana $250 \mathrm{mg}$ besi elemental sebanding dengan $\mathrm{i}$ gram Hb. Dosis pemberian zat besi parenteral dapat dihitung dengan mudah dengan memakai rumus : Zat besi yang diperlukan $(\mathrm{mg})=(15-\mathrm{Hb}) \times \mathrm{BB} \times 3$.

Indikasi : Anemia defisiensi berat, Mempunyai efek samping pada pemberian oral,Gangguan absorbsi.

Pemberian : Dapat diberikan secara Intra-muskular maupun Intra-vena. Peparat : Iron dextran ( ImFeron), Iron sorbitek ( jectoFer ) berisi $50 \mathrm{mg} \mathrm{I} \mathrm{ml,} \mathrm{dosis}$ maksimum 100 mg I hari.

Dosis pemberian zat besi Dosis konsumsi pada ibu hamil ada 2 yaitu :

a. Dosis pencegahan

Tablet tambah darah untuk pencegahan diberikan pada 
ibu hamil tanpa melihat kadar

$\mathrm{Hb}$ yaitu sehari satu tablet $(60$

mg elemental iron dan 0,25

mg asam folat). Ibu hamil

/nifas dianjurkan minum

tablat tambah darah dengan

dosis 1 tablet setiap hari

selama masa kehamilannya 40

hari setelah

melahirkan(Depkes RI,2017).

b. Dosis peongobatan

Bila kadar Hb kurang dari 11

gr\% konsumsi menjadi tiga

tablet sehari selama 90 hari

pada kehamilannya sampai 42

hari setelah melahirkan.

2. Cara Konsumsi Zat besi

Cara yang baik dalam mengkonsumsi tablet Fe adalah :

a. Minum tablet tambah darah dengan air putih, jangan minum dengan teh, susu, kopi karena dapat menurunkan penyerapan zat besi dalam tubuh sehingga manfaatnya menjadi berkurang.

b. Kadang dapat terjadi gejala ringan yang tidak memebahayakan seperti perut terasa tidak enak, mual, susah buang air besar, dan tinja berwarna hitam.

c. Untuk mengurangi gejal sampingan, minum Tablet tambah darah setelah makan malam menjelang tidur. Lebih baik minum tablet tambah darah disertai makan buah- buahan seperti pisang, pepaya, jeruk dan lain- lain.

d. Tablet tambah darah tidak menyebabkan tekanan darah tinggi atau kebanyakan darah.

e. Simpan tablet tambah darah di tempat kering, terhindar dari sinar matahari langsung, jauhkan dari jangkauan anakanak. Setelah dibuka harus ditutup rapat. Tablet tambah darah yang berubah warna jagan diminum (warna asli adalah warna darah/merah).

Jika persediaan cadangan $\mathrm{Fe}$ minimal, maka setiap kehamilan akan menguras persediaan Fe tubuh dan akhirnya menimbulkan anemia pada kehamilan berikutnya. Pada kehamilan, relatif terjadi anemia karena darah ibu hamil mengalami pengenceran dengan peningkatan volume $\quad 30 \%-40 \% \quad$ yang puncaknya pada kehamilan 32-34 minggu. Jumlah peningkatan sel darah 18\%-30\% dan hemoglobin sekitar 19\%. Kebutuhan zat besi pada wanita hamil yaitu rata-rata mendekati 800 mg. Kebutuhan ini terdiri dari, sekitar $300 \mathrm{mg}$ diperlukan untuk janin dan plasenta serta $500 \quad \mathrm{mg}$ lagi digunakan untuk meningkatkan massa haemoglobin maternal. Kurang lebih 200 mg lebih akan dieksresikan lewat usus, urin dan kulit. Makanan ibu hamil setiap 
100 kalori akan menghasilkan sekitar 8-10 $\mathrm{mg}$ zat besi.

Perhitungan makan 3 kali dengan 2500 kalori akan menghasilkan sekitar 20-25 mg zat besi perhari. Selama kehamilan dengan perhitungan 288 hari, ibu hamil akan menghasilkan zat besi sebanyak $100 \mathrm{mg}$ sehingga kebutuhan zat besi masih kekurangan untuk wanita hamil. Dosis yang dianjurkan untuk diminum adalah 1 x 1 tablet perhari sesuai dosis yang dianjurkan. Tetapi apabila terjadi anemia berat dosis bisa dinaikkan menjadi 2 x 1 tablet yang di minum. Namun apabila mengkonsumsi tablet $\mathrm{Fe}$ secara berlebihan akan menimbulkan efek samping yang buruk bagi kesehatan.

Menurut Khomsan (2013) overdosis zat besi akan memicu berbagai efek samping yang merugikan, diantaranya :

a. Masalah Pencernaan

Kelebihan konsumsi
suplemen zat besi akan
memicu berbagai masalah
perut seperti: Mual, muntah,
sembelit, sakit perut dan diare
Setelah mengambil suplemen,
salah satu keluhan umum
yang muncul adalah tinja
yang berwarna gelap yang
disebabkan minimnya
penyerapan zat besi.

b. Perubahan Warna

Kelebihan suplemen zat besi juga dapat menyebabkan perubahan warna gigi, warna kebiruan muncul di bibir, telapak tangan, dan kuku

c. Masalah Kulit

Efek samping kelebihan zat besi juga mengakibatkan gangguan kulit seperti gatal, ruam, pucat dan berkeringat dan pembengkakan mulut atau tenggorokan

d. Keracunan Zat Besi

Keracunan zat besi umumnya dapat diakibatkan asupan berlebihan suplemen zat besi. Beberapa gejala keracunan meliputi: muntah, diare, sakit perut dan darah dalam tinja.

Adapun tindakan pencegahan untuk mencegah kelebihan zat besi diantaranya adalah :

a. Menghindari mengkonsumsi suplemen dengan susu atau produk lain yang kaya kalsium karena akan mengurangi penyerapan zat besi.

b. Mengkonsumsi suplemen setelah makan atau sarapan. Lengkapi diet dengan buah jeruk atau lemon.

c. Untuk mencegah perubahan warna gigi, gunakan sedotan untuk meminum suplemen berbentuk cair. 
d. Pastikan mematuhi dosis yang harus diambil.

Faktor-faktor Penyebab Anemia

1. Gizi

Gizi ibu hamil adalah makanan sehat dan seimbang yang harus dikonsumsi ibu selama masa kehamilan dengan porsi dua kali makanan orang yang tidak hamil (Sulistyoningsih, 2013).

Keadaan gizi ibu sebelum dan selama hamil mempengaruhi status gizi ibu dan bayi. Pertumbuhan dan perkembangan janin sangat dipengaruhi oleh asupan gizi ibu. Kehamilan menyebabkan meningkatnya metabolisme energi, karena itu kebutuhan energi dan zat gizi lainnya meningkat selama kehamilan. Peningkatan energi dan zat gizi tersebut diperlukan untuk pertumbuhan dan perkembangan janin, pertambahan besarnya organ kandungan, perubahan komposisi dan metabolisme tubuh ibu. Sehingga perempuan yang memgalami gangguan gizi sebelum atau atau selama minggu pertama kehamilan memiliki risiko lebih tinggi melahirkan bayi yang mengalami kerusakan otak dan sumsum tulang karena pembentukan sistem sangat peka pada minggu pertama (Mardalena, 2017).
Gizi buruk atau karena penyerapan nutrisi oleh usus menurun juga dapat menyebabkan seseorang kekurangan darah. Demikianjuga padawanita hamil atau sedang menyusui (laktasi), jika asupan zat besi kurang, besar kemungkinan juga menjadi anemia. Perdarahan saluran cerna, menstruasi berlebihan,serta para pendonor darah yang tidak diimbangi dengan gizi baik dapat menjadi anemia: Kebocoran pada saringan darah di ginjal,juga dapat menyebabkan anemia. Hemoglobin akan terus terbuang bersama urin (hemoglobinuria) dan jumlahnya terus berkurang dalam darah.

2. Akibat Penyakit Kronis Anemia umumnya disebabkan oleh perdarahan kronik. Infeksi cacing tambang dapat menyebabkan perdarahan. Infeksi cacing tambang yang disertai gizi baik tidak akan menimbulkan anemia. Sebaliknya, infeksi cacing dengan gizi buruk, baru akan terjadi anemia. Penyakit kronis juga dapat menjadi faktor penyebab seseorang menjadi anemia. Padajenis inijumlah kasusnya terbanyak kedua setelah anemia karena defisiensi besi. Anemia ini banyak dihubungkan dengan berbagai penyakit infeksi, seperti infeksi ginjal, abses paru, gumpalan nanah di paru, 
pembengkakan pada gelembung paru-paru (Sujarwo, 2009).

3. Perdarahan

Perdarahan akut maupun kronik dapat menyebabkan kekurangan darah. Pada saat terjadi perdarahan yang hebat, mungkin gejala anemia belum tampak. Namun, penurunan kadar $\mathrm{Hb}$ baru terjadi beberapa hari kemudian. Transfusi darah merupakan tindakan penanganan utama jika terjadi perdarahan hebat. Perdarahan kronik biasanya tidak kita sadari. Pengeluaran darah biasanya berlangsung sedikit demi sedikit dan berlangsung lama.

Perdarahan di usus karena infeksi cacing atau karena pemakaian analgesik, serta mimisan (epistaksis) yang berkepanjangan dapat pula menyebabkan anemia. Selain itu para gadis remaja dan wanita dewasa kehilangan darah dalam jumlah yang banyak terjadi akibat menstruasi (Djamilus, 2007).

4. Konsumsi Tablet Fe

Ketidakpatuhan ibu dalam mengkonsumsi tablet fe mengakibatkan absorpsi Zat Besi Rendah. Bentuk zat besi yang terdapat dalam tablet fe dan rendahnya zat besi dalam makanan mempengaruhi penyerapan zat besi oleh tubuh. Ada dua macam zat besi dalam makanan, yaitu hem dan nonhem. Zat besi hem berasal dari hewan, penyerapannya tidak tergantung pada jenis makanan lain dan lebih mudah diserap dibanding zat besi nonhem. Pada umumnya zat besi nonhem terdapat pada pangan nabati seperti pada sayur-sayuran, biji-bijian dan buah-buahan (Sujarwo, 2009).

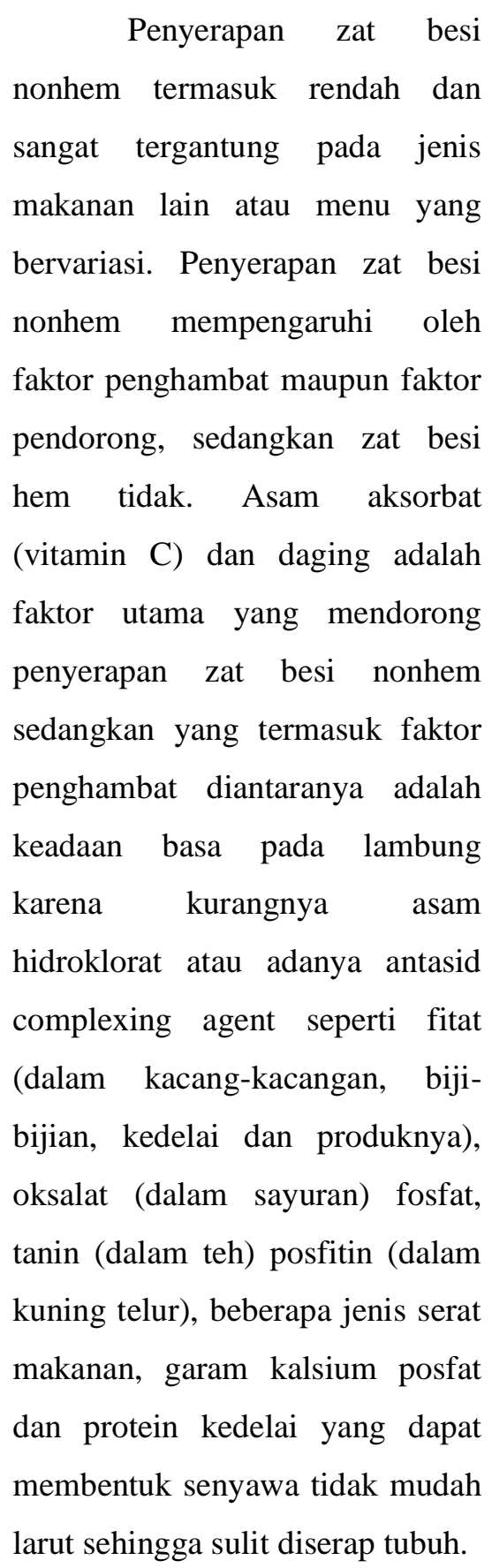


Untuk itu vitamin $\mathrm{C}$
sangat berperan dalam meningkatkan penyerapan zat besi dalam tubuh. Peningkatan konsumsi vitamin C sebanyak 25250 mg dapat memperbesar penyerapan zat besi 2-5 kali. Sedangkan konsumsi bahan pangan yang mengandung zat penghambat seperti teh dan lainlain harus dikurangi karena zat tersebut akan membentuk senyawa yang tak larut dalam air sehingga tidak dapat diabsorpsi.

5. Jarak kehamilan

Jarak kelahiran adalah waktu sejak ibu hamil sampai terjadinya kelahiran berikutnya. Jarak kelahiran yang terlalu dekat dapat menyebabkan terjadinya anemia. Hal ini dikarenakan kondisi ibu masih belum pulih dan pemenuhan kebutuhan zat - zat gizi belum optimal, sudah harus memenuhi kebutuhan nutrisi janin yang dikandung. Berdasarkan analisis data 'diperoleh bahwa reponden paling banyak menderita anemia pada jarak kehamilan $<2$ tahun. Hasil uji memperlihatkan bahwa jarak kelahiran mempunyai risiko lebih besar terhadap kejadian anemia (Kartono, 2011).

Salah satu penyebab yang dapat mempercepat terjadinya anemia pada wanita adalah jarak kelahiran pendek. Pada penelitian ini menunjukkan adanya kecendrungan bahwa semakin dekat jarak kehamilan, maka akan semakin tinggi angka kejadian anemia. Saat hamil seorang wanita memerlukan tambahan zat besi untuk meningkatkan sel darah merah janin dan plasenta. Makin sering seorang wanita mengalami kehamilan dan melahiran akan makin banyak kehilangan zat besi dan menjadi makin anemis.

Kehamilan dan persalinan membutuhkan banyak energi dan kekuatan tubuh perempuan. Bila seorang perempuan belum pulih dari satu persalinan tapi sudah hamil lagi, tubuhnya tidak sempat memulihkan kebugaran berbagai masalah bahkan juga bahaya kematian di hadapinya. Menurut karakteristik kesehatan ibu sebelum dan ketika hamil, kematian neonatal banyak terjadi pada kelompok umur 20-39 tahun, pada anak pertama, dan pada ibu dengan paritas 3 ke atas, kehamilan ke dua dan ketiga adalah paling tidak menyulitkan, sedangkan komplikasi meningkat setelah anak ke tiga. Sebagian besar dari kematian neonatal ibunya tidak mengalami komplikasi ketika hamil.

Jarak kelahiran dapat menyebabkan hasil kehamilan yang kurang baik. Jarak dua kehamilan yang terlalu pendek akan mempengaruhi daya tahan 
dan gizi ibu yang selanjutnya akan mempengaruhi hasil produksi. Jumlah kelahiran yang baik agar terwujudnya keluarga sejahtera dan sehat adalah berjumlah 2 anak saja dengan jarak kelahiran sama dengan atau lebih dari 3 tahun. Penambahan cairan tubuh (volume plasma).

Pada saat hamil darah mengalami pengenceran (hemodilusi) yang ditandai dengan peningkatan volume plasma 30-40\% yang puncaknya terjadi pada usia kehamilan 32 sampai 34 minggu. Jumlah peningkatan sel darah 18-30\% dan haemoglobin sekitar 19\%. Bila haemoglobin ibu sebelum hamil sekitar 11 gr\%, maka dengan terjadinya hemodilusi akan mengakibatkan anemia hamil fisiologis dan $\mathrm{Hb}$ ibu akan menjadi 9,5 gr\%.

6. Zat Besi Dalam Makanan Rendah

Faktor ketidaktahuan dan rendahnya tingkat sosial ekonomi pada ibu hamil merupakan faktor dominan yang menyebabkan rendahnya konsumsi zat besi yang mudah diserap. Contoh bahan makanan yang mudah diserap oleh tumbuhan ialah hati, daging dan ikan. Bahan makanan yang berasal dari tumbuhan yang mengandung zat besi contohnya kacang kedelai, kacang tanah dan sayuran yang berwarna hijau.
Zat besi merupakan mineral yang diperlukan untuk membuat zat warna darah yang terdapat dalam sel darah merah, bila makanan sehari-hari kurang mengandung zat besi, butir darah akan menjadi pucat dan disebut dengan anemia (Riswan, 2008).

7. Paritas

Paritas adalah jumlah anak yang telah dilahirkan oleh seorang ibu baik lahir hidup maupun lahir mati. Seorang ibu yang sering melahirkan mempunyai risiko mengalami anemia pada kehamilan berikutnya apabila tidak memperhatikan kebutuhan nutrisi.Karena selama hamil zat zat gizi akan terbagi untuk ibu dan untuk janin yang dikandungnya.

Klasifikasi paritas dapat digolongkan sebagai berikut (Siswosudarmo, 2010):

1) Primipara adalah seorang yang telah melahirkan seorang anak matur atau prematur

2) Multipara adalah seorang wanita yang telah melahirkan lebih dari satu anak sampai 4 anak

3) Grandemulti adalah seorang wanita yang telah melahirkan 5 orang anak atau lebih

Karakteristik kesehatan ibu sebelum dan ketika hamil, kematian neonatal banyak terjadi pada kelompok umur 20-39 tahun 
pada anak pertama, dan pada ibu dengan paritas 3 ke atas, kehamilan ke dua dan ketiga adalah paling tidak menyulitkan, sedangkan komplikasi meningkat setelah anak ke tiga. Sebagian besar dari kematian neonatal ibunya tidak mengalami komplikasi ketika hamil (Indrawati, 2015)

Anemia pada ibu hamil adalah suatu keadaan risiko yang berpengaruh terhadap Angka Kematian Ibu, dimana anemia bukan merupakan penyebab utama, tetapi anemia merupakan akibat sampingan dari keadaan patologis atau suatu penyakit tertentu. Beberapa faktor penyebab anemia adalah status gizi, penyakit kronik, perdarahan, jarak kehamilan, absorpsi zat besi rendah, penambahan cairan tubuh (volume plasma) dan zat besi dalam makanan rendah. selain itu faktor predisposisi yang terkait dengan karakteristik demografi ibu hamil diantaranya paritas, umur, pendidikan dan jarak kehamilan.

\section{METODE PENELITIAN}

Jenis penelitian yang digunakan dalam penelitian ini termasuk kuantitatif dengan metode analitik dan pendekatan cross sectional. Nursalam (2014) yang mengatakan bahwa pendekatan cross sectional pengukuran data variabel bebas (independent) dan variabel terikat (dependent) hanya satu jali pada satu saat.
Dengan metode ini dapat menggambarkan secara akurat mengenai hubungan konsumsi tablet $\mathrm{Fe}$ dengan kejadian anemia pada ibu hamil.

Populasi dalam penelitian ini adalah ibu hamil trimester III di Desa Baregbeg wilayah kerja Puskesmas Baregbeg Kabupaten Ciamis Februari April tahun 2018 yang berjumlah 31 orang.

Sampel yaitu ibu hamil trimester III yang berlokasi di Desa Baregbeg dijadikan sebagai sampel.

Teknik Pengumpulan Data

1. Data Primer

Data primer yaitu data yang langsung diperoleh dari responden, data tersebut diantaranya adalah identitas responden (nama, umur, alamat) dikumpulkan melalui kuesioner. Selain itu data primer lainnya adalah mengenai konsumsi tablet fe ibu hamil selama kehamilan yang direkap ke dalam format isian serta perolehan data tentang kadar $\mathrm{Hb}$ yang direkap ke dalam format isian.

2. Data sekunder

a. Data topografi wilayah puskesmas Baregbeg didapatkan dari data di puskesmas Baregbeg Kabupaten Ciamis. Data populasi ibu hamil yang diberikan tablet $\mathrm{Fe}$ di wilayah kerja puskesmas Indihiang didapatkan dari data di puskesmas Baregbeg Kabupaten Ciamis.

Rancangan Analisis Data

a. Analisis Univariat 
Analisis univariat adalah analisis

dimana analisis ini akan menghasilkan distribusi frekuensi untuk setiap variabel. Sebelum dilakukan analisis data penulis menyeleksi terlebih dahulu kelengkapan hasil kuesioner kemudian dilakukan tabulasi sehingga frekuensi setiap jawaban dapat diketahui. Teknik pengolahan data yang penulis gunakan ialah dengan distribusi frekuensi yaitu cara perhitungan presentase dari hasil jawaban kuesioner. Caranya yaitu dengan membagi distribusi responden berdasarkan kategori (F) dengan jumlah sampel $(\mathrm{N})$ dan dikalikan $100 \%$ dengan rumus (Somantri, 2007):

$$
P=\frac{n}{N} \times 100 \%
$$

Dimana : $\mathrm{n}=$ Jumlah responden berdasarkan ketegori $\mathrm{N}=$ Jumlah seluruh sampel $100 \%=$ Bilangan tetap $\mathrm{P} \quad=$ Persentase $(\%)$

b. Analisis Bivariat

Analisa bivariat yang dilakukan terhadap dua variabel yang diduga berhubungan atau berkorelasi (Notoatmojo, 2010). Metode yang digunakan untuk melihat hubungan kedua variabel tersebut yaitu dengan menggunakan uji statistik. Uji statistik yang digunakan yaitu dengan menggunakan uji Chi-Square $x^{2}=\sum \frac{\left(f_{0}-f_{h}\right)^{2}}{f_{h}}$

Keterangan:

$\mathrm{X}^{2} \quad=$ chi kuadrat

$\mathrm{F}_{0} \quad=$ Frekuensi observasi

$\mathrm{F}_{\mathrm{h}} \quad=$ Frekuensi harapan

(Arikunto, 2010).

Uji statistik untuk menguji hubungan dua variabel dimana masing-masing terdiri dari beberapa golongan atau kategori dengan tingkat signifikan $5 \%$ (nilai $\alpha=0,05$ ), dengan ketentuan sebagai berikut :

a. Jika $p$ value $\leq \alpha$, maka Ho ditolak yang berarti ada hubungan antara variabel bebas dan variabel terikat.

b. Jika $p$ value $>\alpha$, maka Ho diterima yang berarti tidak ada hubungan antara variabel bebas dan variabel terikat.

Penelitian ini dilakukan pada periode April sampai Juni 2017 yang bertempat di desa Baregbeg wilayah kerja Puskesmas Indihiang Kecamatan Indihiang Kota tasikmalaya. Disamping itu pertimbangan efisiensi biaya penelitian dan lokasi penelitian ini dekat dengan tempat tinggal peneliti.

\section{HASIL DAN DISKUSI}

Pelayanan di Puskesmas Baregbeg terdiri dari pelayanan, pengobatan dasar, pemeriksaan kesehatan ibu dan anak, pemeriksaaan gigi, pelayanan keluarga berencana, unit gawat darurat, 
Jurnal Keperawatan Galuh

Volume : 1-Nomor : 1 Tahun : 2019

pemeriksaan laboratorium sederhana, dan

beberapa pelayanan kesehatan lainnya,

semua pelayanan kesehatan yang

diberikan oleh Puskesmas Indihiang

merupakan pelayanan kesehatan gratis

yang di fokuskan pada masyarakat kurang

mampu yang berdomisili di Kecamatan

Indihiang.

1. Karakteristik responden

a. Usia ibu

$$
\text { Berdasarkan hasil }
$$

penelitian mengenai identitas

responden diketahui sebagian

besar usia 20-35 tahun, untuk

lebih jelasnya dapat dilihat pada

tabel berikut:

Tabel 1

Distribusi responden berdasarkan usia di Desa Baregbeg Puskesmas Baregbeg Kabupaten Ciamis 2018

\begin{tabular}{lcc}
\hline \multicolumn{1}{c}{ Usia ibu } & Frekuensi & Persentase $(\boldsymbol{\%})$ \\
\hline$<20$ tahun & 7 & 22.6 \\
\hline $20-35$ tahun & 19 & 61.3 \\
\hline$>35$ tahun & 5 & 16.1 \\
\hline Total & 31 & 100.0 \\
\hline
\end{tabular}

Data pada tabel 5. menunjukkan

bahwa sebagian besar usia ibu termasuk pada kelompok usia 20-

35 tahun yaitu sebanyak 19orang

(61.3\%), usia > 35 tahun sebanyak
5 orang $(16.1 \%)$ dan usia $<20$ tahun sebanyak 7 orang (22.6\%).

b. Graviditas

Berdasarkan hasil penelitian diketahui paritas ibu diketahui sebagian besar multigravida, untuk lebih jelasnya dapat dilihat pada tabel berikut :

Tabel 2.

Distribusi responden berdasarkan graviditas di Desa Baregbeg Puskesmas Baregbeg Kabupaten Ciamis 2018

\begin{tabular}{l}
\hline \multicolumn{2}{c}{ Graviditas } \\
\hline Primigravida \\
\hline Multigravida \\
\hline Grandegravida \\
\hline Total \\
\hline Data pada tabel 2 \\
menunjukkan bahwa sebagian \\
besar paritas ibu termasuk \\
pada kelompok multigravida \\
yaitu sebanyak 19 orang \\
(61.3\%), primigravida \\
sebanyak 9 orang $(29.0 \%)$ dan
\end{tabular}

c. Pendidikan

Berdasarkan hasil penelitian diketahui pendidikan ibu diketahui sebagian tamat SMA, untuk lebih jelasnya dapat dilihat pada tabel berikut : 
Tabel 3

Distribusi responden berdasarkan pendidikan di Desa Baregbeg Puskesmas Baregbeg Kabupaten Ciamis 2018

\begin{tabular}{lcc}
\hline Pendidikan & Frekuensi & Persentase $(\%)$ \\
\hline Tamat SD & 8 & 25.8 \\
\hline Tamat SMP & 5 & 16.1 \\
\hline Tamat SMA & 18 & 58.1 \\
\hline Total & 31 & 100.0 \\
\hline
\end{tabular}

Data pada tabel 3

menunjukkan bahwa sebagian

besar pendidikan responden

lulusan dari tamat SMA yaitu

sebanyak 18 orang (48.9\%),

dari SD sebanyak 8 orang

(25.8\%) dan dari SMP

sebanyak 5 orang (16.1\%). d. Pekerjaan

Berdasarkan hasil penelitian diketahui pekerjaan ibu diketahui sebagian besar bekerja sebagai IRT, untuk lebih jelasnya dapat dilihat pada tabel berikut:

Tabel 4

Distribusi responden berdasarkan pekerjaan di Desa Baregbeg Puskesmas Baregbeg Kabupaten Ciamis 2018

\begin{tabular}{|c|c|c|}
\hline Pekerjaan & Frekuensi & Persentase $(\%)$ \\
\hline Buruh & 6 & 19.4 \\
\hline IRT & 419 & 61.3 \\
\hline Tani & 3 & 9.7 \\
\hline Wiraswasta & 3 & 9.7 \\
\hline Total & 31 & 100.0 \\
\hline
\end{tabular}

Data pada tabel 4 menunjukkan bahwa sebagian besar pekerjaan responden adalah sebagai IRT yaitu sebanyak 19 orang (59.6\%)dan sebagian kecil sebagai tani dan wiraswasta masing-masing 3 orang $(9.7 \%)$.

2. Analisis Univariat a. Konsumsi Tablet fe

Berdasarkan hasil penelitian mengenai perilaku ibu hamil dalam mengkonsumsi tablet $\mathrm{Fe}$ sebagian besar termasuk kategori teratur. Untuk lebih jelasnya dapat dilihat pada tabel

berikut: 
Tabel 5

Distribusi frkuensi konsumsi tablet Fe pada ibu hamil di Desa Baregbeg Puskesmas Baregbeg Kabupaten Ciamis 2018

\begin{tabular}{|c|c|c|}
\hline Konsumsi tablet Fe & Frekuensi & Persentase (\%) \\
\hline Teratur & 17 & 54.8 \\
\hline Tidak teratur & 14 & 45.2 \\
\hline Total & 31 & 100.0 \\
\hline Data pada tabel & 5 & Hasil penelitian \\
\hline menunjukkan & & diperoleh \\
\hline sebagian besar ibu & & pemeriksaan \\
\hline teratur mengkonsumsi & & diperoleh data \\
\hline Fe yaitu sebanyak 17 & & sebagian besar responden \\
\hline$(54.8 \%)$ dan yang & & tidak mengalami \\
\hline $\begin{array}{l}\text { teratur sebanyak } 14 \\
(45.2 \%) \text {. }\end{array}$ & & $\begin{array}{l}\text { untuk lebih jelasnya dapat } \\
\text { dilihat pada tabel berikut: }\end{array}$ \\
\hline
\end{tabular}

b. Kejadian anemia

Tabel 6

Distribusi frekuensi kejadian anemia pada ibu hamil di Desa Baregbeg Puskesmas Baregbeg Kabupaten Ciamis 2018

\begin{tabular}{lcc}
\hline \multicolumn{1}{c}{ Kejadian anemia } & Frekuensi & Persentase $(\%)$ \\
\hline Tidak anemia $(\mathrm{Hb} \geq 11 \mathrm{gr} \%)$ & 19 & 61.3 \\
\hline Anemia $(\mathrm{Hb}<11 \mathrm{gr} \%)$ & 12 & 38.7 \\
\hline Total & 31 & 100.0 \\
\hline
\end{tabular}

Data pada tabel 6 menunjukkan bahwa sebagian besar ibu hamil tidak mengalami anemia yaitu sebanyak 19 orang $(61.3 \%)$ dan yang mengalami anemia sebanyak 12 orang (38.7\%).

3. Analisis Bivariat

Tabel 7

Hubungan konsumsi tablet fe dengan kejadian anemia pada ibu hamil di Desa Baregbeg Wilayah Kerja Puskesmas Baregbeg Kabupaten Ciamis tahun 2018

\begin{tabular}{lccccccc}
\hline \multirow{2}{*}{$\begin{array}{l}\text { Konsumsi } \\
\text { tablet Fe }\end{array}$} & \multicolumn{4}{c}{ Kejadian Anemia } & \multicolumn{2}{c}{ Total } & \multirow{2}{*}{ P value } \\
\cline { 2 - 6 } & \multicolumn{2}{c}{ Tidak } & \multicolumn{2}{c}{ Anemia } & & & \\
\cline { 2 - 7 } & F & $\mathbf{\%}$ & F & \% & Jml & $\mathbf{( \% )}$ & \\
\hline Teratur & 15 & 88.2 & 2 & 11.8 & 17 & 100 & $\mathbf{0 . 0 0 2}$ \\
\hline $\begin{array}{l}\text { Tidak } \\
\text { teratur }\end{array}$ & 4 & 28.6 & 10 & 71.4 & 14 & 100 & \\
\hline Jumlah & $\mathbf{1 9}$ & $\mathbf{6 1 . 3}$ & $\mathbf{1 2}$ & $\mathbf{3 8 . 7}$ & $\mathbf{3 1}$ & $\mathbf{1 0 0}$ & \\
\hline
\end{tabular}

Data pada tabel .7 menunjukkan bahwa dari ibu hamil yang teratur mengkonsumsi tablet $\mathrm{Fe}$ sebanyak 15 orang $(88.2 \%)$ diantaranya tidak mengalami anemia. Dari ibu hamil yang tidak teratur mengkonsumsi tablet Fe sebanyak 10 orang $(71.4 \%)$ diantaranya 
mengalami anemia. Berdasarkan hasil uji statistik dengan menggunakan chi square diperoleh nilai $\mathrm{p}=0,002$ dengan menggunakan $\alpha=0,05$, maka nilai $\mathrm{p} \leq \alpha$, maka dapat disimpulkan $\mathrm{Ha}$ diterima berarti terdapat hubungan yang signifikan antara konsumsi tablet tambah darah dengan kejadian anemia pada ibu hamil.

Pembahasan Hasil Penelitian

1. Perilaku mengkonsumsi tablet Fe. Hasil penelitian ini dapatkan bahwa sebagian besar ibu hamil teratur mengkonsumsi tablet $\mathrm{Fe}$ yaitu sebanyak 17 orang (54.8\%) dan yang tidak teratur sebanyak 14 orang (45.2\%). Data tersebut menunjukkan bahwa kurang dari setengah responden tidak teratur atau tablet $\mathrm{Fe}$ tersebut tidak diminum setiap hari/ setiap malam.

Seluruh ibu hamil mengakui mendapat tablet atau supelemen dari tenaga kesehatan yang harus dikonsumsi setiap malam, saat melakukan pemeriksaan kehamilan ke bidan.

Dari hasil penelitian ini peneliti berpendapat adanya ibu hamil yang tidak teratur mengkonsumsi tablet Fe mengindikasikan adanya kekurangan zat besi dalam darah ibu karena tidak terpenuhinya zat besi sehingga dapat menyebabkan anemia.
Walaupun dalam hal ini peneliti tidak melakukan pengkajian terhadap faktor yang mempengaruhi perilaku namun dari hasil penelitian didapatkan sebagian besar usia ibu termasuk pada kelompok usia 20-35 tahun, data tersebut mengindikasikan bahwa usia ibu termasuk dewasa muda dimana padausia tersebut lebih matang dalam berfikir dan bertindak. Menurut Notoatmodjo (2010) mengemukakan umur dapat mempengaruhi seseorang, semakin cukup umur tingkat kemampuan; kematangan seseorang akan lebih matang dalam berpikir dan menerima informasi.

Terkait dengan paritas sebagian besar adalah multigravida, kondisi ini menunjukkan bahwa ibu multigravida mempunyai pengalaman dari kehamilan atau persalinan sebelumnya. Responden beranggapan bahwa pada kehamilan yang sudah dijalani tidak mengalami komplikasi sehingga enggan mengkonsumsi tablet $\mathrm{Fe}$. Selanjutnya pendidikan responden lulusan dari tamat SD, rendahnya pendidikan juga dapat menggambarkan intelektual seseorang sehingga dengan rendahnya pendidikan berpengaruh pada perilaku. Data 
lain ditemukan sebagian besar pekerjaan responden adalah sebagai IRT, dengan demikian responden memiliki waktu luanguntuk mencari informasi mengenai tablet $\mathrm{Fe}$, namun kenyataannya responden kadangkadang mengkonsumsi tablet fe hal ini disebabkan karena adanya faktor psikis seperti lupa atau malas untuk mengkonsumsi tablet Fe.

$$
\text { Hasil penelitian }
$$

ditemukan responden memperoleh tablet Fe dari petugas kesehatan namun tidak dikonsumsinya secara teratur sebagaimana yang telah dianjurkan oleh bidan. Walaupun dalam penelitian ini penulis tidak menelusuri lebih jauh alasan responden mengkonsumsi tablet $\mathrm{Fe}$ tidak teratur, kondisi ini diduga karena ibu merasakan mual-mual setelah mengkonsumsi tablet tersebut yang mengakibatkan ibu merasa enggan untuk melanjutkannya

Mengkonsumsi tablet $\mathrm{Fe}$
secara tidak teratur dapat
mengakibatkan zat besi tidak
dapat diabsorbsi secara optimal.

Konsumsi zat besi tidak boleh dihentikan setelah hemoglobin mencapai nilai normal, tetapi harus dilanjutkan selama 2-3 bulan lagi untuk memperbaiki cadangan besi (Ramayulis, 2015).

Pemberian zat besi selama 2-3 bulan setelah hemoglobin menjadi normal, yang penting dalam pengobatan dengan zat besi adalah agar pemberiannya diteruskan dahulu sampai morfologi darah tepi menjadi normal dan cadangan besi dalam tubuh terpenuhi. Sebelum dilakukan pengobatan harus dikalkulasikan terlebih dahulu jumlah zat besi yang dibutuhkan (Maurer 2015).

Cara mengkonsumsi tablet $\mathrm{Fe}$ secara tidak teratur ini akan berdampak pada efektifitas penambahan sel darah merah tidak optimal. Padahal kadar $\mathrm{Hb}$ ini dapat diperbaiki dengan mengkonsumsi tablet penambah darah yang telah diberikan oleh petugas kesehatan. Pemberian tablet Fe sebanyak 90 butir selama kehamilan yang sebenarnya cukup untuk memenuhi kebutuhan zat besi bagi ibu hamil dan janin.

Dalam upaya meningkatkan perilaku ibu hamil dalam mengkonsumsi tablet $\mathrm{Fe}$, maka perlu kiranya dilakukan pendidikan kesehatan yang berkesinambungan seperti dalam kelas ibu hamil, melakukan skrining atau deteksi pada ibu hamil untuk memantau konsumsi tablet fe dengan melibatkan kader kesehatan.

2. Kejadian anemia

Hasil penelitian didapatkan sebagian besar ibu hamil tidak 
mengalami anemia yaitu sebanyak 19 orang (61.3\%) dan yang mengalami anemia sebanyak 12 orang $(38.7 \%)$. Hasil pemeriksaan kadar hemoglobin dengan menggunakan $\mathrm{Hb}$ sahli haemometer menunjukkan bahwa sebagian besar responden dengan hemoglobin mencapai $11 \mathrm{~g} / \mathrm{dL}$. Kondisi ini memperlihatkan bahwa ibu hamil tidak mengalami kekurangan darah, artinya zat besi (Fe) pada ibu hamil dapat memenuhi kebutuhan baik ibu maupun janin yang dikandungnya.

Data lain ditemukan adanya ibu hamil yang mengalami anemia dalam arti kadar HB ibu dibawah $11 \mathrm{~g} / \mathrm{dl}$, kondisi demikian merupakanindikasi bahwa kebutuhan zat besi selamakahmil tidak terpenuhi, mislanya yang bersumber dari tabelt $\mathrm{Fe}$ tidak teratur mengkonsumsinya. Sehingga kebutuhan tablet $\mathrm{Fe}$ pada ibu hamil dapat berkurang dan akhirnya menganggu absorpsi zat gizi. Masa kehamilan keperluan akan zat-zat makanan bertambah dan terjadi pula perubahan-perubahan dalam darah dan sum-sum tulang.

Namun dalam hal ini penulis tidak menemukan adanya ibu hamil yang mengalami riwayat penyakit kronis, artinya anemia yang terjadi pada ibu hamil bukan disebabkan oleh penyakit kronis, namun ada hal lain yang mempengaruhinya seperti pendidikan ibu, usia anak terakhir dan jumlah anak.

Pengaruh keadaan anemia terhadap kehamilan bergantung pada derajat anemia. Jika anemia ringan, mungkin pengaruhnya hampir tidak ada, namun jika hemoglobin di bawah $6 \mathrm{~g} / \mathrm{dL}$, ibu akan merasa lekas lelah, bahkan dapat terjadi gangguan fungsi jantung. Dengan demikian kehamilan dapat menimbulkan anemia karena pada kehamilan terjadi peningkatan volume darah sehingga sel darah merah relatif menjadi lebih rendah.

3. Hubungan konsumsi dan anemia

Hasil penelitian didapatkan bahwa dari ibu hamil yang teratur mengkonsumsi tablet Fe sebanyak 15 orang $(88.2 \%)$ diantaranya tidak mengalami anemia. Dari ibu hamil yang tidak teratur mengkonsumsi tablet Fe sebanyak 10 orang $(71.4 \%)$ diantaranya mengalami anemia.

Ketidakpatuhan ibu dalam mengkonsumsi tablet fe mengakibatkan absorpsi Zat Besi Rendah. Hal ini memperjalas dari hasil uji statistik dengan menggunakan chi square diperoleh nilai $\mathrm{p}=0,002$ dengan menggunakan $\alpha=0,05$, maka nilai $\mathrm{p} \leq \alpha$, maka dapat disimpulkan $\mathrm{Ha}$ diterima berarti terdapat hubungan 
yang signifikan antara konsumsi tablet tambah darah dengan kejadian anemia pada ibu hamil.

$$
\text { Yunita (2012) dalam }
$$

penelitiannya menemukan bahwa ibu hamil yang tidak teratur mengkonsumsi tablet $\mathrm{Fe}$ sebesar 22 responden $(62,9 \%)$. Kejadian anemia sebesar 19 responden $(54,3 \%)$. Hasil analisis uji chisquaredidapatkan $\rho(0,000)<\alpha$ $(0,05)$ sehingga $\mathrm{HO}$ ditolak artinya ada hubungan antara keteraturan mengkonsumsi tablet $\mathrm{Fe}$ dengan kejadian anemia pada ibu hamil. Kesimpulannya adalah semakin banyak ibu hamil yang tidak teratur mengkonsumsi tablet $\mathrm{Fe}$ semakin tinggi resiko kejadian anemia..

Bentuk zat besi yang terdapat dalam tablet fe dan rendahnya zat besi dalam makanan mempengaruhi penyerapan zat besi oleh tubuh. Ada dua macam zat besi dalam makanan, yaitu hem dan nonhem. Zat besi hem berasal dari hewan, penyerapannya tidak tergantung pada jenis makanan lain dan lebih mudah diserap dibanding zat besi nonhem. Pada umumnya zat besi nonhem terdapat pada pangan nabati seperti pada sayur-sayuran, biji-bijian dan buah-buahan (Sujarwo, 2009).

Penyerapan zat besi
nonhem termasuk rendah dan

sangat tergantung pada jenis makanan lain atau menu yang bervariasi. Penyerapan zat besi nonhem dipengaruhi oleh faktor penghambat maupun faktor pendorong, sedangkan zat besi hem tidak. Asam aksorbat (vitamin C) dan daging adalah faktor utama yang mendorong penyerapan zat besi nonhem sedangkan yang termasuk faktor penghambat diantaranya adalah keadaan basa pada lambung karena kurangnya asam hidroklorat atau adanya antasid complexing agent seperti fitat (dalam kacang-kacangan, bijibijian, kedelai dan produknya), oksalat (dalam sayuran) fosfat, tanin (dalam teh) posfitin (dalam kuning telur), beberapa jenis serat makanan, garam kalsium posfat dan protein kedelai yang dapat membentuk senyawa tidak mudah larut sehingga sulit diserap tubuh.

Untuk itu vitamin $\mathrm{C}$ sangat berperan dalam meningkatkan penyerapan zat besi dalam tubuh. Peningkatan konsumsi vitamin C sebanyak 25-250 $\mathrm{mg}$ dapat memperbesar penyerapan zat besi 2-5 kali. Sedangkan konsumsi bahan pangan yang mengandung zat penghambat seperti teh dan lain-lain harus dikurangi karena zat tersebut akan membentuk senyawa yang tak larut dalam air sehingga tidak dapat diabsorpsi. 


\section{KESIMPULAN DAN SARAN}

Kesimpulan

Berdasarkan uraian hasil penelitian dan pembahasan mengenai hubungan konsumsi tablet fe dengan kejadian anemia pada ibu hamil di Desa Baregbeg Wilayah Kerja Baregbeg Kabupaten Ciamis tahun 2018 dengan jumlah sampel penelitian sebanyak $31 \mathrm{ibu}$ hamil dapat disimpulkan sebagai berikut:

1. Konsumsi tablet fe pada ibu hamil di Desa Baregbeg Wilayah Kerja Puskesmas Baregbeg Kabupaten Ciamis tahun 2018 sebagian besar termasuk kategori teratur (54.8\%).

2. Ibu hamil di Desa Baregbeg Wilayah Kerja Puskesmas Baregbeg Wilayah Kerja Puskesmas Baregbeg Kabupaten Ciamis tahun 2018 sebagian besar tidak mengalami anemia (61.3\%)

3. Terdapat hubungan konsumsi tablet fe dengan kejadian anemia pada ibu hamil di Desa Baregbeg Wilayah Kerja Baregbeg Wilayah Kerja Puskesmas Baregbeg Kabupaten Ciamis tahun 2018 dengan $\mathrm{p}$ value 0.002 .

Saran

1. Bagi Ibu Hamil

Sebaiknya ibu hamil dapat mengkonsumsi tablet $\mathrm{Fe}$ secara teratur sesuai dengan anjuran dari petugas kesehatan sehingga dapat mencegah kejadian anemia.

2. Bagi Puskesmas

Sebaiknya pihak Puskesmas dapat memberikan promosi Kesehatan dengan Pendekatan Kepada
Masyarakat

dengan

Komunikasi,Edukasi,Informasi,Motiv asi (KEIM) kepada masyarakat khususnya ibu hamil mengenai konsumsi tabelt $\mathrm{Fe}$ melalui penyebaran leaflet, brosur ataupun pendidikan kesehatan yang dilakukan pada saat kegiatan Posyandu, Pengjian ataupun kegiatan lain.

3. Bagi Peneliti lain

Sebaiknya dilakukan penelitian lain yang berhubungan dengan perilaku ibu mengkonsumsi tablet $\mathrm{Fe}$ menggunakan faktor lain yang lebih luas dan menggunakan metode yang lebih mendalam seperti metode kualitatif.

\section{REFERENSI}

Arikunto, 2010. Prosedur Penelitian, Suatu Pendekatan Praktek;Edisi Revisi PT. Asdi Mahasatya

Amanda (2013). Faktor-Faktor Yang Berhubungan Dengan Kepatuhan Ibu Hamil Dalam Mengkonsumsi Tablet Zat Besi Di Wilayah Kerja Puskesmas Tanah Garam Kota Solok

Brunner 2015. Keperawatan medikal bedah. Jakarta: EGC.

DepKes RI, 2016. Pedoman Pemberian Besi Bagi Petugas, Jakarta.

Dinas Kesehatan Kabupaten Ciamis, 2017. Ramayulis (2015). dalam kehamilan. http://www.mediacastore.com [30 Januari 2017] dr.Taufan N, 2012. Patologi Kebidanan. Nuha Medika. Yogyakarta 
Volume : 1-Nomor : 1 Tahun : 2019

Harnawatiaj, 2008. Perubahan Anatomi dan Fisiologi wanita Hamil.

Hendro. 2006. Mengatasi penyebab anemia Kurang gizi. http://www.ipb.ac.id diakses tahun 2017

Indrawati, 2010. Panduan Perawatan Kehamilan. Jogjakarta. Atma Media Press

Karyadi 2015. Ibu Hamil di Indonesia Mengalami Anemia

Kemenkes RI, 2016. Profil Kesehatan Indonesia.

Http://www.depkes.go.id

Mansjoer, 2009. Kapita Selekta Kedokteran. Aescepalus. Jakarta Mardalena,2017. Pustaka Baru Pres,Dasar - dasar Ilmu Gizi dalam Keperawatan, Jakarta

Manuaba, 2008. Ilmu Kebidanan dan Keluarga Berencana untuk Pendidikan Bidan. EGC. Jakarta.
Maurer. 2015. Pengembangan Model Monitoring Konsumsi Tablet Besi bagi Ibu hamil di Tingkat Keluarga.

Notoatmodjo. 2010. Ilmu Kesehatan Masyarakat: Teori dan Aplikasi. Rhineka Cipta. Jakarta

Riduwan,2011. Belajar Mudah Penelitian. Alfabeta. Bandung

Saifuddin, 2010. Ilmu Kebidanan. Yayasan Bina Pustaka Sarwono Prawirohardjo Jakarta.

Sediaoetama (2009). Ilmu Gizi. Jakarta. Penerbit Dian Rakyat.

Suanita. 2017. Status Gizi Dengan Anemia Pada Ibu Hamil Sulistyoningsih, H. 2013. Gizi Kesehatan Ibu dan Anak. Graha Ilmu. Jogjakarta

Widowati. 2012. Jarak Kehamilan dengan Kejadian Anemia Dalam 